\section{УДК: 616.26-007.43-031]-007.271-089-053.2:616.358-007.61}

DOI: $10.24061 / 2413-4260 . X I .3 .41 .2021 .9$

\section{S. Babuci', O. Gorbatyuk', V. Eremia ${ }^{1}$, V. Petrovici ${ }^{1}$}

IMSP Mother and Child Institute ${ }^{1}$

Nicolae Testemitanu State University

of Medicine and Pharmacy ${ }^{1}$

(Chisinau, Republic of Moldova)

Національний університет охорони здоров'я

імені П.Л.Шупика МО3 України ${ }^{2}$

(м.Київ, Україна)

\section{SPONTANEOUS RUPTURE OF THE RIGHT CONGENITAL DIAPHRAGMATIC EVENTRATION ON THE RIGHT SUBJECTED TO SURGICAL CORRECTION IN A CHILD WITH MEGADOLICOCOLON}

Summary. Spontaneous rupture of the hemidiaphragm in cases of congenital diaphragmatic eventration is extremely rare, with unique cases being reported in the literature.

In this context, the authors present the case of an 8-year-old child who was hospitalized in the coloproctology service for abdominal pain, lack of stool for more than 7 days, pronounced abdominal distension. The child suffers from Down's disease. In 2017, he was occasionally diagnosed with right diaphragmatic eventration and underwent surgical correction by thoracic approach. After a thorough evaluation, with signs suggestive of diaphragmatic hernia on the right, the child underwent surgery, intraoperatively the rupture of the right hemidiaphragm was found with intrathoracic ascension of the malrotated intestinal loops, transverse colon and omentum. The repair of the diaphragmatic eventration complicated by rupture was used using the "overcoat" folding procedure, on the suture line being carefully applied a collagen foil covered with components of the fibrin adhesive. The postoperative period passed without complications.

Conclusion. Spontaneous rupture of the diaphragm is a rare complication in children with diaphragmatic eventration, especially on the right side, in this case obstruction of the malformative colon ascended intrathoracically with progressive dilation of the intestinal loops being responsible for distension with gradual thinning of the hemidiaphragm sac resulting malformation in diaphragmatic rupture with herniation and progressive obliteration of the pleural space. The case of rupture of the diaphragmatic eventration associated with megadolicocolon confirms that the respiratory symptoms characteristic of this clinical situation may be overshadowed by the predominance of signs of intestinal obstruction, without leading to sudden progressive clinical deterioration, which proved to be a misleading moment in diagnosis. certainty of this serious complication rarity.

Keywords: Ruptured Diaphragm; Diaphragmatic Eventration; Congenital Diaphragmatic Defect; Congenital abnormalities.

\section{Introduction}

Diaphragmatic eventration (ED) is a partial or total abnormal ascent of the hemidiaphragmatic dome, as a result of embryological development defects of the diaphragm muscle (congenital form) or following traumatic injury of the phrenic nerve (acquired form) at birth or during surgery the mediastinum [9, 31].

In the literature is reported an incidence ranging from $0.02-0.07$ to $1-3$ cases per 1000 newborns, constituting about $5 \%$ of diaphragmatic diseases $[12,14]$.

Spontaneous rupture of the hemidiaphragm in cases of congenital diaphragmatic eventration is extremely rare, with unique cases being reported in the literature $[11,22]$.In this context, we present a case of congenital diaphragmatic eventration complicated by rupture of the affected hemidiaphragm in a child with congenital megacolon.

Case presentation. Patient G, male, aged 8 years was hospitalized in the coloproctology service for abdominal pain, lack of stool for more than 7 days, pronounced abdominal distension. The child suffers from Down's disease and was institutionalized, and later adopted. There was no history of trauma.

The anamnestic data allowed to concretize that from the age of 5-6 months the child presents severe constipation, daily encopresis, being found also data of hypothyroidism, malnutrition, psychosomatic retardation. In 2017, he was occasionally diagnosed with right diaphragmatic eventration, which underwent surgical correction by thoracic approach.
Subsequently, the patient disappeared under the supervision of specialists.

On examination - the child was active, running, there was a moderate dyspnea on physical exertion, the abdomen significantly distended, asymmetrical, being palpated multiple hard fecal matter. Asymmetric thorax with limited respiratory movements on the right, auscultatively being found the absence of breathing on the right associated with intestinal gargoyle. The heart tones were rhythmic, periodically tachycardia being observed (Ps $120 \mathrm{rpm}$ ).

On deep palpation, the abdomen was sensitive throughout the area, with no signs of peritoneal irritation. At rectal cough, fecal masses of extremely hard consistency were determined, impacted, being established the provisional diagnosis of decompensated chronic colostasis, intestinal obstruction with fecalomas.

After 72 hours of colonic disinfection, a thoracoabdominal radiograph was performed, where it was found that the right hemithorax was occupied almost entirely by the ascended intestinal loops (fig. 1). At the irigographic examination (barium enema) the rectal functional area and the dislocation of the colon in the right hemithorax (megadolicocolon) were found (fig, 2).

In contrast-enhanced chest CT, subtotal prolapse of the pronounced dilated intestinal loops and colon was found in the right hemithorax with moderate contralateral displacement of the mediastinum. right lung and flattening of the right hemidiaphragm (fig. 3) 


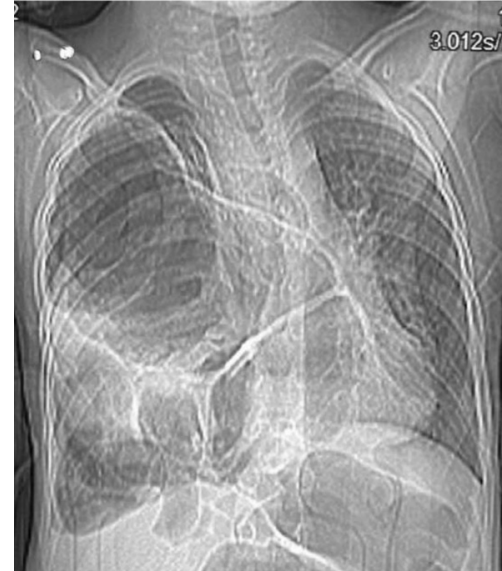

Fig. 1. Patient G., 8 years old. Chest $X$-ray at the time of admission. Explanationsinthetext.

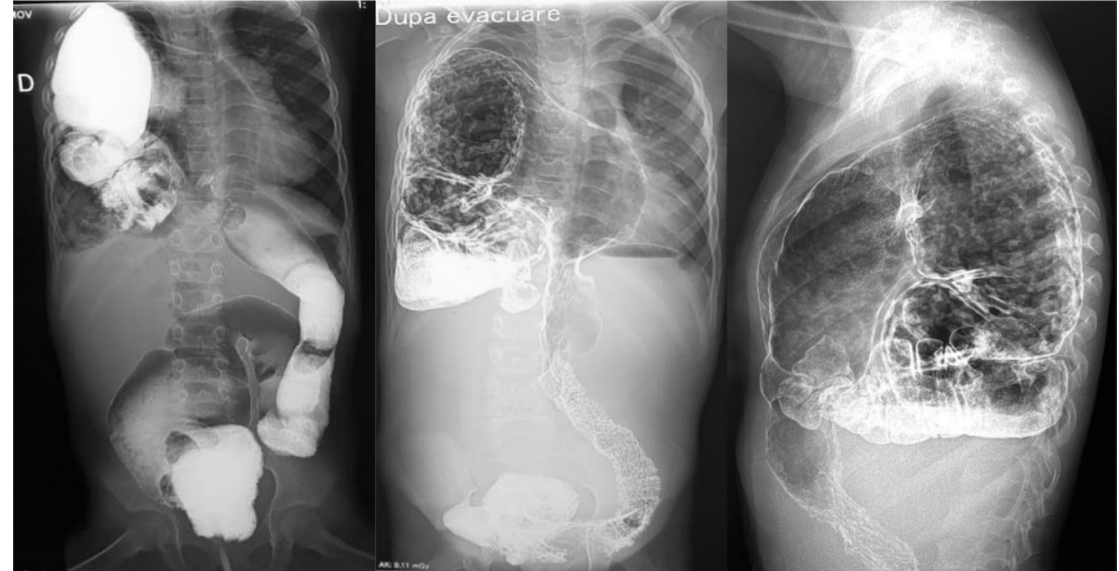

Fig. 2. The contrast substance is visualized in the projection of the small and large intestine (intraabdominal loops and intrathoracic loops on the right).

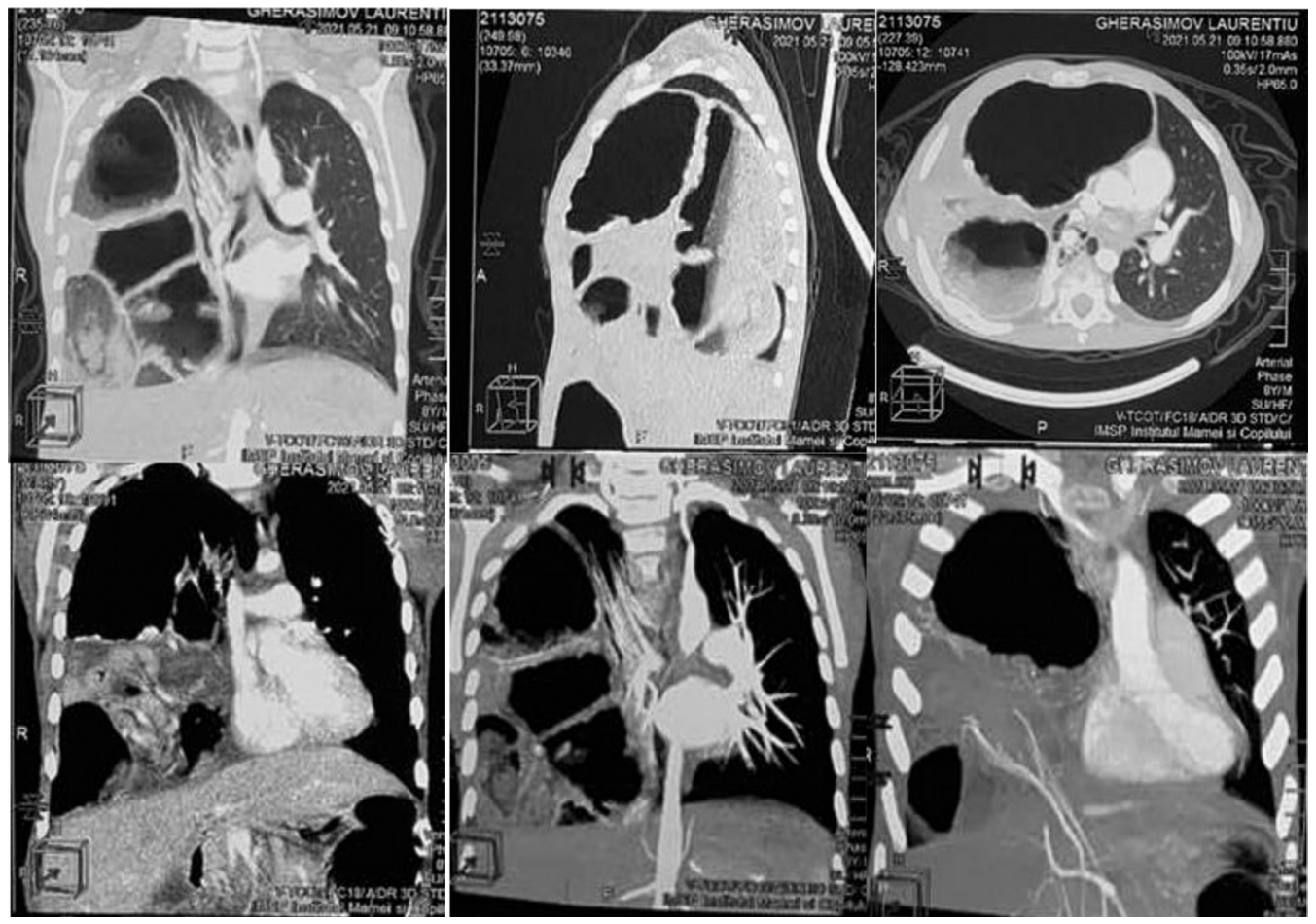

Fig. 3. Patient G., 8 years old. Preoperative CT scan. Explanations in the text.

Echocardiography revealed an insignificant dilation of the right ventricular cavity; the function of the left ventricle being within normal limits; insufficiency of the tricuspid valve gr.I; pulmonary valve insufficiency grade I; mild hypertension (PSAP -32 mmHG).

Evaluation of hematological parameters found a leukocytosis $(11.8 \times 109 / 1)$, anemia gr. I (106 g/l), low hematocrit $(30.5 \%)$ and lymphopenia $(22 \%)$. The parameters of the arterial gases in the blood were at a normal level.

After a preoperative preparation, under general anesthesia, surgery was performed, practicing a superior median laparatomy. The revision determined the ascent in the right hemithorax cavity of the loops of the malrotated small intestine, the transverse colon and the omentum through an anatomical defect of about $8 \times 4 \mathrm{~cm}$, appeared by rupture of the diaphragmatic sac, located in the anterior-medial region of the right hemidiaphragm, which was significantly distended. and thin, the changes being characteristic for congenital eventration of the diaphragm (fig. 4A, B). Note that the edges of the rupture were scarred.

The revision of the organs of the abdominal cavity determined the presence of megadolicolon (fig. 5A) and multiple interintestinal adhesions, which formed knees with strangulation of the loops of the small intestine (fig. 5B), as well as a defect in the omentum (fig. 5C), which imposed the need to perform the adhesiolysis procedure with suturing the omentum defect.

On macroscopic evaluation of the right lung by defect, it was hypoplasia, the lower and middle lobe being atelectasis. It was resorted to repair the diaphragmatic eventration complicated by rupture using the "overcoat" folding procedure, on the suture line being carefully applied a collagen foil covered with components of fibrin adhesive. The intervention ended with the restoration of the anatomical plane and the drainage of the pleural cavity on the right after 
Bulau. The thoracic drain was removed after 72 hours postoperatively with radiological control (fig. 6). The postoperative period passed without complications, the patient being discharged on the 10th postoperative day.

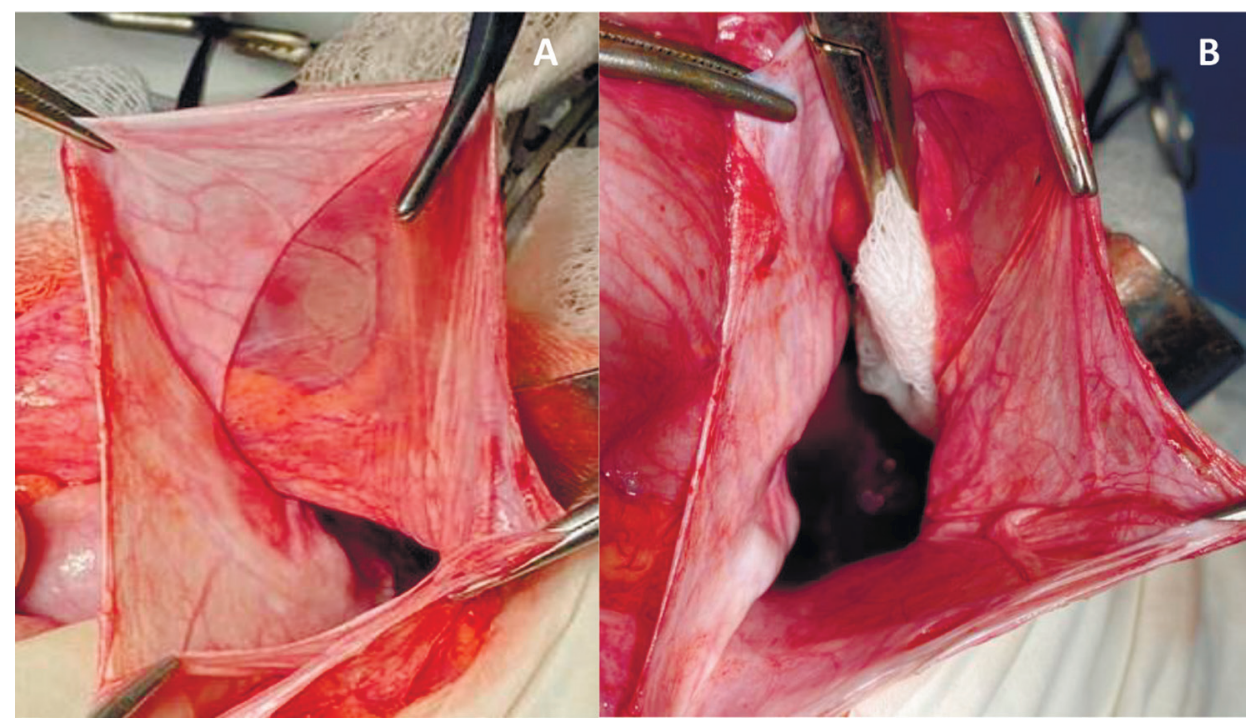

Fig. 4.Intraoperative appearance of the right hemidiaphragm sac, which is distended and thinned, and anatomical defect created by rupture

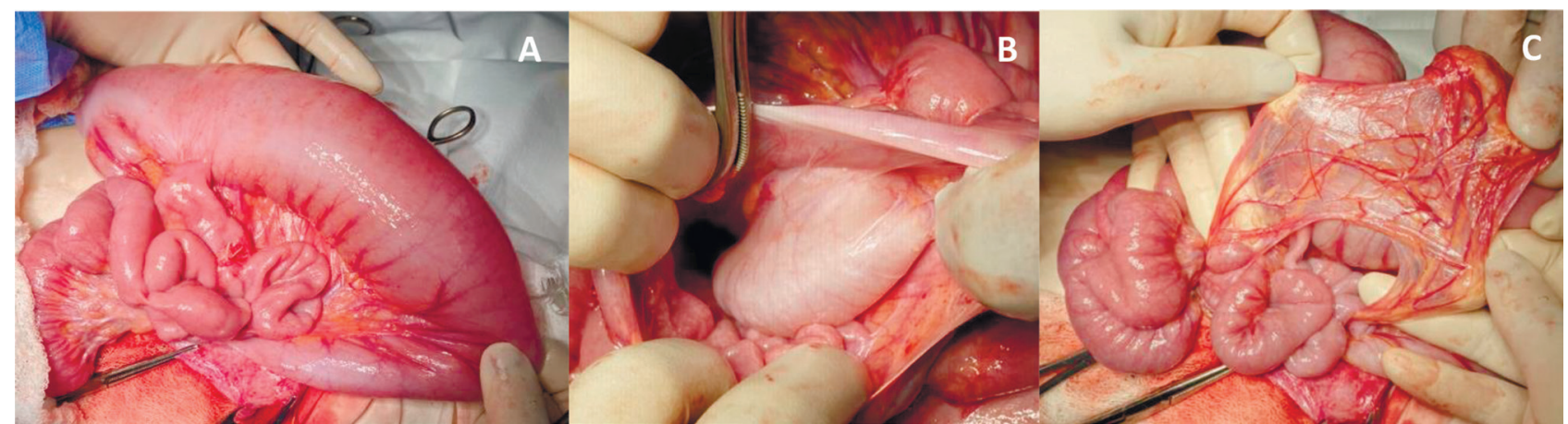

Fig. 5. Intraoperative aspect: A - signs of megadolicocolon, B - interintestinal adhesions, which formed knees with strangulation of the intestine; C - defect of the omentum

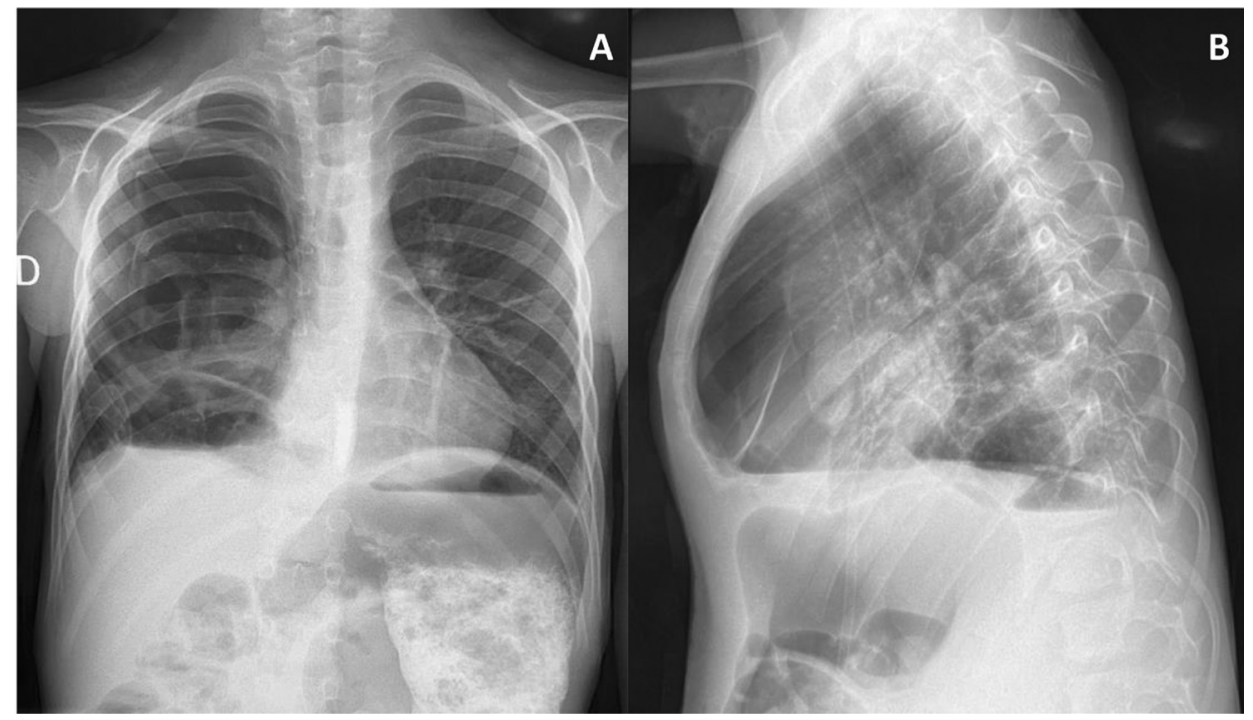

Fig. 6. Patient G., 8 years old. Chest radiograph performed at 72 hours postoperatively: visualize open air and supradiaphragmatic fluid, the right lung being partially re-expanded. Numerous pleuro-diaphragmatic and pleuro-pulmonary adhesions are observed. Atelectric component in the projection of the middle lobe on the right. The mediastinum shifted to the left insignificant. Permeable contrasting esophagus of ordinary caliber. The air bubble of the stomach is detected subdiaphragmally on the left. 
Pulmonary scintigraphy with Tc99m MAA performed at the time of discharge determined a pronounced diffuse decrease in pulmonary blood flow in the right lung, the pulmonary blood flow on the left being within normal limits (fig. 7).

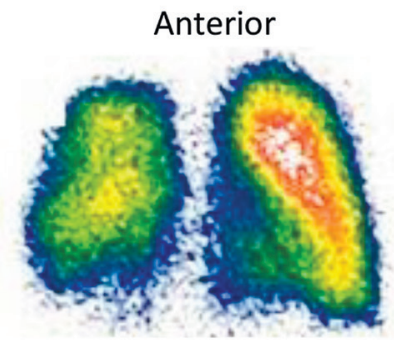

D

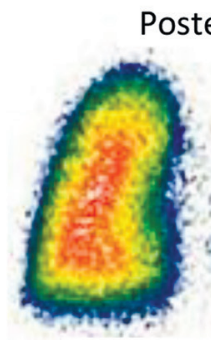

L

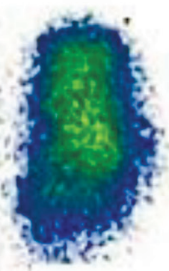

D
Fig. 7. Patient G, 8 years old.

Postoperative lung scintigraphy.

Explanations in the text.

The results of the histological examination were also in favor of the diagnosis of diaphragmatic eventration, which highlighted a polymorphic morphological picture of the tissue plates taken from different areas of the malformative hemidiaphragm, which was presented by dysplastic connective tissues. dense fibrous connective tissue that serves as a mechanical support for the diaphragm. At the same time, in the muscular area of the malformative hemidiaphragm, among the mass of loose connective tissue, numerous chaotically dispersed muscle bundles were attested (fig. 8A). In some tissue samples, along with the presence of fibrous sclerosing processes, chronic inflammatory changes have been documented, in some places with the development of an adhesion process (fig. 8B).

\section{Discussions}

The first diaphragmatic eventration was described in 1774 by Jean Louis Petit. The term eventration was originally proposed by Beclard in 1829. In 1935, Feldman L. in his famous paper considered the name eventration to be wrong, because this term suggests the movement of organs outside the abdominal cavity. Subsequently, in the literature this pathological condition was described using several names, including: elevation, relaxation, high position, insufficiency, dilation, etc. However, the term eventration received a specific connotation for this pathological condition of the diaphragm [3, 4, 8, 25].

Diaphragmatic eventration is a congenital defect of rare development of the muscular portion of the diaphragm. From a histological point of view, this malformation is characterized by fibroelastic, dysplastic changes, which replace the layer of muscle tissue and extend between the pleura and peritoneum, keeping intact the anatomical structure of the diaphragm, which differs from congenital diaphragmatic hernias and diaphragmatic paralysis. The incidence of this malformation is below $0.05 \%[29,30]$.

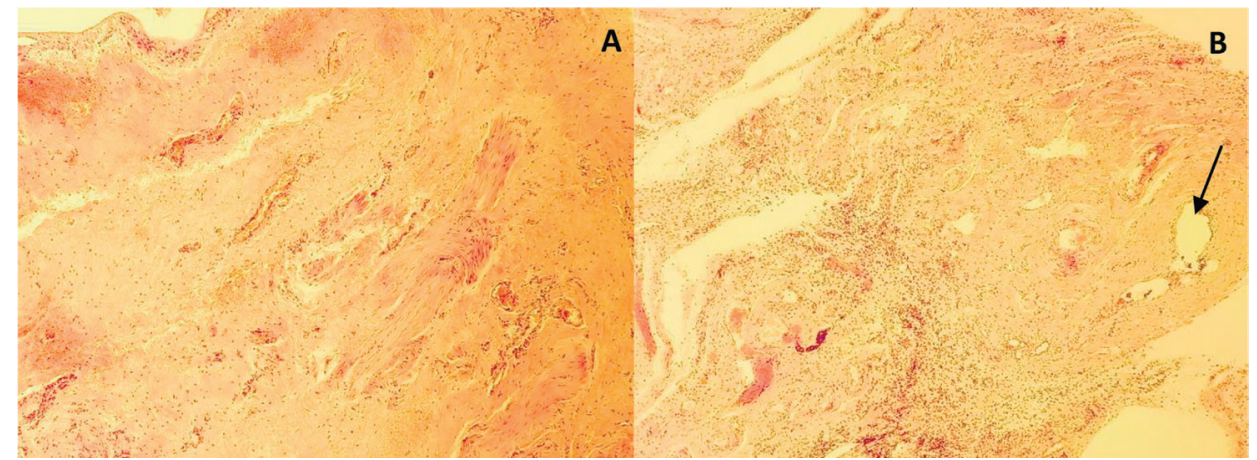

Fig. 8. Microstructural features found in diaphragmatic eventration in patient G .: A - muscle bundles chaotically distributed in the thickened areas of the malformative hemidiaphragm (sagging); B - chronic and scarring-adhesion inflammatory process with arterio-venous vascular device and cystic ectasia lymphatics (arrow). Color. H-E.
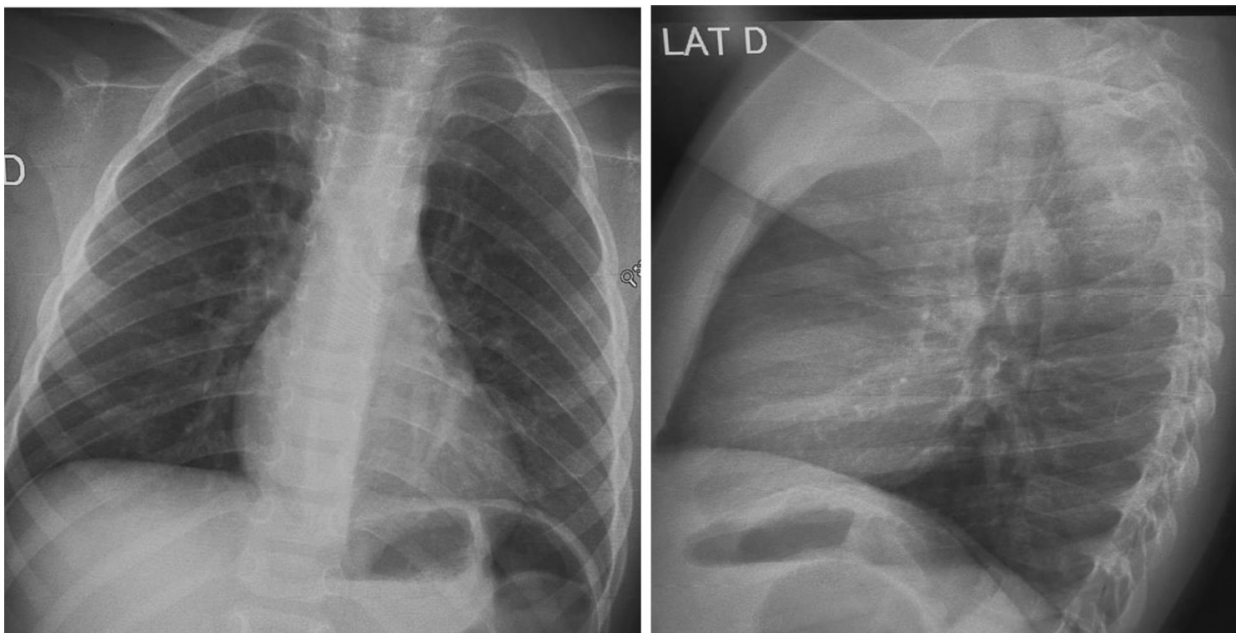

Fig. 9. Chest X-ray at 60 days postoperatively in two incidence. Lungs of normal volume. Accentuated lung drawing. At the moment there is no evidence of pneumonic opacity. Clear mediastinal and diaphragmatic contour. 
In contrast, Bochdalek or Morgagni hernia, diaphragmatic eventration is not characterized by an anatomical defect of the pleura or peritoneum, however this malformation is considered a diaphragmatic defect because abnormal elevation of the hemidiaphragm allows invasion of the intraperitoneal viscera into the thoracic space [3]. The left hemidiaphragm is more commonly affected. Congenital diaphragmatic eventrations are divided into: complete, partial. Partial eventrations, based on embryological segments, which contribute to the formation of the normal diaphragm, can be classified into the following types: anterior, posterolateral and medial [10, 29]. Bilateral impairment is described [16].

Spontaneous or traumatic diaphragmatic ruptures in children are rare, more commonly found on the left side, probably because the right hemidiaphragm is protected by the liver [11]. Rupture of diaphragmatic eventration, rarely reported in children, can develop without identifying any cause (spontaneous), during physical exertion or caused by violent cough [26]. Postoperative rupture of diaphragmatic eventration after hemidiaphragm folding is also described [5]. A sudden onset of respiratory distress in a child with diaphragmatic eventration should suggest suspicion of diaphragmatic rupture even in the absence of trauma or respiratory disease [22]. In the case presented by us, there was no respiratory symptoms characteristic with the progressive deterioration of the child's condition, the diagnostic difficulties being determined by the predominance of abdominal symptoms.

The indications for surgical treatment in diaphragmatic eventrations are: pulmonary compression with respiratory disorders (tachypnea) without any improvement after conservative treatment, cardiac compression leading to arrhythmias, two or more recurrent ipsilateral pneumonias, severe life-threatening pneumonia, inability to disconnect from mechanical ventilation, respiratory distress associated with paradoxical movements of the diaphragm [17, 29].

Surgical treatment of diaphragmatic eventration in children is indicated not only in symptomatic patients [9], but also in those who are apparently asymptomatic with major disorders of ipsilateral pulmonary function, found at the evaluation of ventilation and perfusion [28, 29]. Diaphragmatic eventration associated with spontaneous rupture of the diaphragm [11], intestinal obstruction [1], symptomatic gastric volvulus or suspected perforation are surgical emergencies in which a subcostal or transverse abdominal incision is most frequently resorted to. This approach makes possible not only the folding of the diaphragm, but also the anterior gastric fixation by a gastropexy or gastrotomy [18, 23].

Although several surgical techniques have been proposed to repair diaphragmatic eventration, including excision and suturing, diaphragmatic splicing, and the use of prosthetic nets [2], the most commonly used technique in eventration and diaphragmatic paralysis is diaphragm splicing $[21,29]$. aiming to reduce the dysfunctional caudal excursion of the diaphragm during inspiration [2]. The application of this procedure to adults was first described in 1923 by Morrison J.N.W. $[10,15,29]$, although it was proposed as early as 1916 by Wood [17]. In children, the first diaphragmatic plication was performed in 1947 by Bisgard on an infant with respiratory failure [24].

Several plication procedures on intact or sectioned diaphragm are described [7, 27]. The "overcoat" application provides for the return of the diaphragmatic dome in tension, making a front envelope, in the shape of a flag, directed towards the pleural cavity, held at the base by a row of non-absorbable U-shaped sutures. Then the retained portion is folded forward, anterior or posterior, and sutured again to the diaphragm with interrupted sutures, thus creating three overlapping layers in the thin part of the diaphragm [17]. We used a similar product in the case presented.

The invagination reversed folding process involves suturing the tight edges of the diaphragm by positioning the excess length to the peritoneal cavity. The first nonabsorbent thread is applied to close the depression at the periphery of the diaphragm. Subsequently, a second surjet is applied above [6, 19].

The central nesting technique consists in applying several linear rows of horizontal non-absorbable sutures through the weakened part of the diaphragm. Along with the sutures, the weak tissues are tightened in the folds, creating a tense diaphragmatic surface [20].

The diaphragmatic folding techniques used have proven to be safe, simple and adequate in the surgical correction of diaphragmatic eventration in children, with good results at a distance. They reduce most preoperative symptoms immediately after surgery and improve lung function [2].

Postoperative complications after diaphragmatic folding include: atelectasis, pneumonia, pleurisy, abdominal compartment syndrome and spleen injuries, usually in the abdominal approach [13].

\section{Conclusion}

Therefore, spontaneous rupture of the diaphragm is a rare complication in children with diaphragmatic eventration, especially on the right side, in this case obstruction of the malformative colon ascended intrathoracically with progressive dilation of the intestinal loops being responsible for distension with the gradual thinning of the hemidiaphragm sac. resulted in diaphragmatic rupture with herniation and progressive obliteration of the pleural space. The case of rupture of the diaphragmatic eventration associated with megadolicocolon confirms that the respiratory symptoms characteristic of this clinical situation may be overshadowed by the predominance of signs of intestinal obstruction, without leading to sudden progressive clinical deterioration, which proved to be a misleading moment in diagnosis. certainty of this serious complication rarity.

\section{Bibliography}

1. Ahmed M, Mirza B, Sheikh A. Eventration of diaphragm presenting as small bowel obstruction. APSP J Case Rep [Internet]. 2010 [cited 2021 May 28];1(2):22. Available from:https://www.ncbi.nlm.nih.gov/pmc/articles/PMC3417999/

2. Alshorbagy A, Mubarak Y. Open transthoracic plication of the diaphragm for unilateral diaphragmatic eventration in infants and children. Korean J Thorac Cardiovasc Surg. 2015;48(5):307-10.doi: 10.5090/kjtcs.2015.48.5.307

3. Carrasco A, Castro R. Right diaphragmatic eventration with an intrathoracic kidney: case report and review of the literature. Case Rep Surg [Internet]. 2018[cited 2021 Jul 12];2018:2631391. Available from:https://www.ncbi.nlm.nih.gov/ pmc/articles/PMC6304889/doi: 10.1155/2018/2631391. 
4. Christensen P. Eventration of the diaphragm. Thorax. 1959;14(4):311-9.doi: 10.1136/thx.14.4.311

5. Ciftci AO, Tanyel FC, Senocak ME, Büyükpamukçu N, Hiçsönmez A. Diaphragmatic rupture after plication: etiopathogenesis with review of the literature. Eur J Pediatr Surg. 1996;6(3):177-9.doi: 10.1055/s-2008-1066502

6. Demos DS, Berry MF, Backhus LM, Shrager JB. Video-assisted thoracoscopic diaphragm plication using a running suture technique is durable and effective. JThoracCardiovascSurg. 2017;153(5):1182-8.doi: 10.1016/j.jtcvs.2016.11.062

7. Favre J-P, Favoulet P, Cheynel N, Benoit L.Surgical treatment of diaphragmatic eventration. EMC-Chirurgie. 2005;2(3):235-41.doi:10.1016/j.emcchi.2005.03.001

8. Feldman L, Trace IM, Kaplan MI. "Eventration" of the right diaphragm: report of a case with review of the literature, chiefly from the standpoint of etiology and diagnosis. Ann Intern Med [Internet]. 1935[cited 2021 Jul 19];9(1):62-77. Available from:https://www.acpjournals.org/doi/pdf/10.7326/0003-4819-9-1-62 doi:10.7326/0003-4819-9-1-62.

9. Ghribi A, Bouden A, Braiki M, Jabloun A, Sghairoun N, Gasmi M, et al. Diaphragmatic eventration in children. Tunis Med. 2015;93(2):76-8.

10. Groth SS, Andrade RS. Diaphragm plication for eventration or paralysis: a review of the literature. AnnThorac Surg. 2010;89(6):S2146-50.doi: 10.1016/j.athoracsur.2010.03.021

11. Gun F, Gunendi T, Erginel B, Guler N, Celik A. Rupture of a congenital diaphragmatic eventration in a child: report of a case. Surg Today. 2011;41(12):1630-2.doi: 10.1007/s00595-010-4475-x

12. Gupta A, Sidler M, van Poll D, Patel N, Eaton S, Muthialu N, et al. Thoracic versus abdominal approach to correct diaphragmatic eventration in children. J Pediatr Surg. 2020;55(2):245-8.doi: 10.1016/j.jpedsurg.2019.10.040

13. Guzman JPS, Santos NCD, Baltazar EA, Baquir ATD. Congenital unilateral diaphragmatic eventration in an adult: A rare case presentation. IntJ Surg Case Rep. 2017;35:63-7. doi: 10.1016/j.ijscr.2017.04.010

14. Guzman-Valderrabano CR, Hernandez-Saldana R, Soto-Ramos M, Hinojos-Gallardo LC. Congenital diaphragmatic eventration in a 9 month patient: case report and review. NeumolCir Torax. 2017;76(1):24-9.

15. Ichiki Y, Korehisa S, Kawasaki J, Hamatsu T, Suehiro T, Koike M, et al. Thoracoscopic plication for idiopathic eventration of the bilateral diaphragm: report of a case. Int J Surg Case Rep. 2015;10:176-8.doi: 10.1016/j.ijscr.2015.04.001

16. Joshi A, Kumar M, Acharya A. Bilateral congenital eventration of diaphragm: keep in mind, the other side. BMJ Case Rep [Internet]. 2018[cited 2021 Aug 7];2018:bcr2018226051. Available from:https://www.ncbi.nlm.nih.gov/pmc/ articles/PMC6194440/ doi: 10.1136/bcr-2018-226051

17. Le Pimpec-Barthes F, Brian E, Vlas C, Gonzalez-Bermejo J, Bagan P, et al. Surgical treatment of diaphragmatic eventrations and paralyses. Rev Maladies Respir. 2010;27(6):565-78.doi: 10.1016/j.rmr.2010.01.015

18. Mandal KC, Barman S, Biswas S, Kumar R, Mukhopadhyay M, Mukhopadhyay B. Eventration of diaphragm with gastric perforation in a child: a rare presentation. Indian AssocPediatrSurg. 2016;21(4):207-8.doi: 10.4103/09719261.186560

19. Mouroux J, Padovani B, Poirier NC, Benchimol D, Bourgeon A, Deslauriers J, et al. Technique for the repair of diaphragmatic eventration. Ann Thorac Surg. 1996;62(3):905-7.doi: 10.1016/s0003-4975(96)00530-9

20. Patrini D, Panagiotopoulos N, Bedetti B, Lawrence D, Scarci M. Diaphragmatic plication for eventration or paralysis. Shanghai Chest [Internet]. 2017[cited 2021 Jul 27];1:25. Available from:https://www.researchgate.net/ profile/Nikolaos-Panagiotopoulos-2/publication/319489570 Diaphragmatic plication for eventration or paralysis/ links/59ee33044585154350e807de/Diaphragmatic-plication-for-eventration-or-paralysis.p $\overline{\mathrm{d} f}$

21. Ravisagar P, Abhinav S, Mathur RM, Anula S. Eventration of diaphragm presenting as recurrent respiratory tract infections - A case report. Egyptian J Chest Dis. Tuberc. 2015;64(1):291-3. doi: 10.1016/j.ejcdt.2014.10.002

22. Saha S, Bal HS, Sen S. Spontaneous rupture of a congenital diaphragmatic eventration in an infant. BMJ Case Rep [Internet]. 2015[cited 2021 Jul 15];2015:bcr2015208634. Available from:https://www.ncbi.nlm.nih.gov/pmc/articles/ PMC4434382/ doi: $10.1136 /$ bcr-2014-208634.

23. Sinwar PD. Gastric mesenteroaxial volvulus with partial eventration of left hemidiaphragm: A rare case report. Int J Surg Case Rep. 2015;9:51-3.doi: 10.1016/j.ijscr.2015.02.034

24. Symbas PN, Hatcher Jr CR, Waldo W. Diaphragmatic eventration in infancy and childhood. Ann Thor Surg. 1977;24(2):113-9.doi: 10.1016/s0003-4975(10)63718-6

25. Thomas TV. Congenital eventration of the diaphragm. Ann Thorac Surg. 1970;10(2):180-92.doi: 10.1016/s00034975(10)65584-1

26. Vinod Kumar MS, Shaw SC, Devgan A. Non-traumatic rupture of eventration of diaphragm in a child. Med J Armed Forces India. 2018;74(3):290-3.doi:10.1016/j.mjafi.2017.05.008

27. Visouli AN, Mpakas A, Zarogoulidis P, Machariotis N, Stylianaki A, et al. Video assisted thoracoscopic plication of the left hemidiaphragm in symptomatic eventration in adulthood. JThorac Dis. 2012;4(1S1):6-16. doi: 10.3978/j.issn.20721439.2012.s001

28. Wu L, Shi J, Chen Q, Jiang G. Congenital multiple eventrations of the right diaphragm in adulthood. J Thorac Cardiovasc Surg. 2014;148(2):735-6. doi: $10.1016 /$ j.jtcvs.2013.12.053

29. Wu S, Zang N, Zhu J, Pan Z, Wu C. Congenital diaphragmatic eventration in children: 12 years' experience with 177 cases in a single institution. J Pediatr Surg. 2015;50(7):1088-92.doi: 10.1016/j.jpedsurg.2014.09.055

30. Ali Shah SZ, Khan SA, Bilal A, Ahmad M, Muhammad G, Khan K, et al. Eventration of diaphragm in adult: eleven years experience. J Ayub Med Coll Abbottabad. 2014;26(4):459-62.

31. Zhao S, Pan Z, Li Y, An Y, Zhao L, Jin X, et al. Surgical treatment of 125 cases of congenital diaphragmatic eventration in a single institution. BMC Surg [Internet]. 2020[cited $2021 \mathrm{Jul} 15$ ];20(1):270. Available from:https://www. ncbi.nlm.nih.gov/pmc/articles/PMC7640684/doi:10.1186/s12893-020-00928-z 


\section{СПОНТАННЫЙ РАЗРЫВ ПРАВОГО КУПОЛА ДИАФРАГМЫ ПРИ ЕГО ЭВЕНТРАЦИИ КАК ПОКАЗАНИЕ К ХИРУРГИЧЕСКОЙ КОРРЕКЦИИ У РЕБЕНКА С МЕГАДОЛИХОКОЛОН}

\author{
С. Бабуч ${ }^{1}$, О. Горбатюк, В. Еремия ${ }^{1}$, В. Петрович ${ }^{I}$
}

\author{
Институт матери и ребенка ${ }^{1}$, \\ Государственный университет медицины \\ и фармации имени Николае Тестемицану ${ }^{1}$ \\ (г. Кишинев, Республика Молдова) \\ Национальный университет охраны здоровья \\ имени П.Л.Шупика МЗ Украины ${ }^{2}$
}

(г. Киев, Украина)

Резюме. Спонтанный разрыв гемидиафрагмы при врожденной диафрагмальной эвентрации встречается крайне редко, в литературе описаны единичные случаи. В этом контексте авторы представляют случай 8-летнего ребенка, который был госпитализирован в колопроктологическое отделение с жалобами на боли в животе, отсутствие стула более 7 дней, выраженное вздутие живота. Ребенок страдает синдромом Дауна. В 2017 году у него диагностировали правостороннюю диафрагмальную эвентрацию и провели хирургическую коррекцию торакальным доступом. После тщательного обследования, с признаками, указывающими на диафрагмальную грыжу справа, ребенку была проведена операция. Интраоперационно был обнаружен разрыв правой гемидиафрагмы с внутригрудным восхождением мальротированных кишечных петель, поперечной ободочной кишки и сальника. Для устранения диафрагмальной эвентрации, осложненной разрывом, использовали методику складывания "шинели", где на линию шва аккуратно накладывали коллагеновую пленку, покрытую компонентами фибринового адгезива. Послеоперационный период прошел без осложнений.

Заключение. Спонтанный разрыв диафрагмы является редким осложнением у детей с диафрагмальной эвентрацией, приемущественно справа. В данном случае обструкция мальформационной толстой кишки, расположенная в грудной полости с прогрессирующим расширением кишечных петель, привела к дилатации и постепенному истончению гемидиафрагмального мешка, разрыву диафрагмы с образованием грыжи и прогрессирующей облитерации плевральной полости.

Случай разрыва диафрагмальной эвентрации, связанный с мегадоликолоном, подтверждает, что дыхательные симптомы, характерные для данной клинической картины, могут быть скрыты преобладающими признаками кишечной непроходимости, не приводящие к внезапному прогрессирующему клиническому ухудшению, что явилось ошибочным моментом при диагностике этого редкого осложнения.

Ключевые слова: разрыв диафрагмы; эвентрация диафрагмы; врожденный дефект диафрагмы; врожденные аномалии.

\section{СПОНТАННИЙ РОЗРИВ ПРАВОГО КУПОЛУ ДІАФРАГМИ ПРИ ЙОГО ЕВЕНТРАЦІЇ ЯК ПОКАЗАННЯ ДО ХІРУРГІЧНОЇ КОРЕКЦІї У ДИТИНИ $З$ МЕГАДОЛІХОКОЛОН}

\author{
С. Бабуч ${ }^{1}$, О. Горбатюк ${ }^{2}$ В. Еремія $^{1}$ В. Петрович ${ }^{1}$
}

Інститут матері і дитини ${ }^{1}$,

Державний університет медицини та фармації імені Миколи Тестеміцану ${ }^{1}$

(м. Кишинів, Республіка Молдова)

Національний університет охорони здоров'я імені П.Л.Шупика МОЗ України (м.Київ, Україна)

Резюме. Спонтанний розрив гемідіафрагми при вродженій діафрагмальній евентрації зустрічається вкрай рідко, у літературі описані поодинокі випадки. У цьому контексті автори представляють випадок 8-річної дитини, яка була госпіталізована в колопроктологічне відділення зі скаргами на болі в животі, відсутність стільця більше 7 днів, виражене здуття живота. Дитина страждає на синдром Дауна. У 2017 році у неї діагностували правосторонню діафрагмальную евентрацію і провели хірургічну корекцію торакальним доступом. Після ретельного обстеження, з ознаками, що вказують на діафрагмальну грижу праворуч, дитині була проведена операція. Інтраопераційно був виявлений розрив правої гемідіафрагми 3 внутрішньогрудним сходженням мальротованих кишкових петель, поперечної ободової кишки і сальника. Для усунення діафрагмальної евентрації, ускладненої розривом, використовували методику складання «шинелі», де на лінію шва акуратно накладали колагенову плівку, покриту компонентами фібринового адгезіва. Післяопераційний період пройшов без ускладнень.

Висновок. Спонтанний розрив діафрагми є рідкісним ускладненням у дітей 3 діафрагмальною евентрацією, головним чином справа. У даному випадку обструкція мальформаційної товстої кишки, яка знаходиться у грудній порожнині з прогресуючим розширенням кишкових петель, призводить до ділатації і поступового потонщення гемідіафрагмального мішка, розриву діафрагми з утворенням грижі і прогресуючої облітерації плеврального простору.

Випадок розриву діафрагмальної евентрації, пов'язаний 3 мегадоліколоном, підтверджує, що дихальні симптоми, характерні для даної клінічної ситуації, можуть бути приховані переважаючими ознаками кишкової непрохідності, що не призводять до раптового прогресуючого клінічного погіршення, що стало помилковим моментом при діагностиці цього рідкісного ускладнення.

Ключові слова: розрив діафрагми; евентрація діафрагми; вроджений дефект діафрагми; вроджені аномалії.

\section{Контактна інформація:}

Горбатюк Ольга Михайлівна - доктор медичний наук, професор, Заслужений лікар України, завідувач кафедри дитячої хірургії Національного університету охорони здоров'я імені П.Л.Шупика МОЗ України (м.Київ, Україна)

e-mail: ol.gorbatyuk@gmail.com

ORCID ID: orcid.org/0000-0002-1472-5737.

Scopus Author ID: https://www.scopus. com/authid/detail.uri?authorld $=6602182209$

\section{Контактная информация:}

Горбатюк Ольга Михайловна - доктор медицинский наук, профессор, Заслуженный врач Украины, заведующая кафедры детской хирургии Национального университета охраны здоровья имени П.Л.Шупика МЗ Украины (г. Киев, Уукраина) e-mail: ol.gorbatyuk@gmail.com ORCID ID: orcid.org/0000-0002-1472-5737. Scopus Author ID: https://www.scopus.com/ authid/detail.uri?authorld $=6602182209$

\section{Contact Information:}

Olga Gorbatyuk - MD, Professor, Honored Doctor of Ukraine, Chief of the Department of Pediatric Surgery, National University of Health Protection named after P.L. Shupyk, Ministry of Health of Ukraine

Address: Shupyk National Medical Academy of Postgraduate Education, Department of

e-mail: ol.gorbatyuk@gmail.com

ORCID ID: orcid.org/0000-0002-1472-5737.

Scopus Author ID: https://www.scopus. com/authid/detail.uri?authorld=6602182209 